\title{
Presence of Africa in African-American \\ Literature
}

Dr. Lekha Nath Dhakal ${ }^{1}$

\begin{abstract}
:
African traditions and rituals survived the antagonistic forces which transported them from their ancestral lands to other continents is an established fact in world history. However, how they have been employed in varied artistic forms still requires further investigation. The traditions and rituals still practiced by the people of African diaspora in various parts of the globe are connected to Africa. These primitive traditions stored both orally and in written form are abundantly found in African-American literature.
\end{abstract}

\section{Keywords:}

Africa, black, literature, tradition

The African tradition in African-American literature is an aesthetic that embodies many different ways in which the African-American writer explores Africa and her importance to both the black and the world. This tradition appears in varied forms in poetry and prose. During slavery, Africa was viewed in African-American literature and songs as a lost homeland, an image intensely remembered. In the twentieth century due to Civil Rights, Black Power and Black Arts Movements, Africa is regained, and the African tradition in African-American literature emerged as a fascinating memory of a lost native land that culminated into a cultural reunion of blacks.

Many critics such as Robert A. Bone's The Negro Novel in America (1965), Addison Gayle's edition of Black Aesthetic (1972) and The Way of the New World (1975) have studied the way Africa is portrayed. They advanced the notion of African-American culture whose destiny was inexorably linked with African culture.

Amiri Baraka's Home (1975) created a new consciousness in the way AfricanAmerican literature was created and studied. Other remarkable works that highlight African culture in African-American literature are Houston A. Baker's The Journey Back (1980) and Blues, Ideology, and Afro-American Literature: A Vernacular Theory (1984); Robert Stepto's From Behind the Veil (1979) and Afro-American Literature: The Reconstruction of Instruction (1979); and Henry Louis Gates, Jr.'s The Signifying Monkey (1988) and Figures in the Black (1987).

1 Associate Professor of English, Nepal Commerce Campus, New Baneshwor 
Gates' views on black literature may be limited to two premises. First, he argues that the theory of reading black texts is inherent in the "vernacular tradition," traceable to Eshu in African mythology. Eshu, an African god, is a messenger of the Supreme Being, a trickster and an intermediary between humanity and destiny; he is "benevolent as well as malevolent, ambiguous and mischievous" (Herskovits 253). Among many cultural traits which the African-American brought to the New World is the concept of Eshu, who has been transformed into the Signifying Monkey in American vernacular tradition. Gates states: "Within New World African-informed cultures, the presence of this topos, repeated with variations as circumstances apparently dictated, attests to shared belief systems maintained for well over three centuries, remarkably, by sustained vernacular traditions. We can trace this particular topos ultimately to the Fon and Yoruba cultures of Benin and Nigeria" (Signifying Monkey 4). The signifying monkey "contains a primal scene of instruction for the act of interpretation" (4). Thus, the critique of African-American literature requires an exploration into the topos' relationship with African cultural heritage. Gates stresses his notion further:

The black Africans who survived the dreaded "Middle Passage" from the west coast of Africa to the New World did not sail alone. Violently and radically abstracted from their civilizations, these Africans nevertheless carried within them to the Western hemisphere aspects of their cultures that were meaningful, that could not be obliterated, and that they chose, by acts of will, not to forget: their music (mnemonic device for Bantu and Kwa tonal languages), their myths, their expressive institutional structures, their metaphysical systems of order, and their forms of performance. If "the Dixie Pike," as Jean Toomer put the matter in Cane, "has grown from a goat path in Africa," then Black vernacular tradition stands as its signpost, at that liminal crossroads of culture contact and ensuing difference at which Africa meets Afro-America. (Signifying Monkey 4)

Gates' second premise is that African-American writers signify on one another in acts of revising, where signifying can mean repetition. Thus, succeeding generations of writers revise their predecessors, adding, modifying, and borrowing motifs to create pastiche. He explains, "Ours is repetition, but repetition with a difference, a signifying black difference" (Black Literature and Literary Theory 3). Gates' premises are similar to the theoretical basis of literary indebtedness that is so central to comparative literature studies (Shaw 97).

The structure, theme, and vision of the African-American folktales owe much to African folktales. The early African-American story tellers recreated African trickster stories in which vulnerably small animals usually outwit their larger enemies. Adapting the 
narrative strategies of their new creations to the New World natural environment, they made some practical substitutions. Thus, where African animals such as tortoise, spider, and hare represent the assailed underdog of the African folk narrative, the African-American story tellers created Brer Rabbit. The larger animal adversaries or predators such as lion, tiger, elephant, and hippopotamus to which the African narrative trickster is vulnerable become bear, lion, and fox. In the 1880 Joel Chandler Harris collected and edited African-American folk narratives, titled Uncles Remus: His Songs and His Sayings. The animal trickster character of African-American folk narratives was later transformed into human fictional characters such as Tar Baby, a clever diminutive of a person whose prodigious resources usually assist him to defeat slave masters.

African traditions appear also in that segment of African-American literature called "slave narratives" or "the locus classicus of Afro-American literary discourse" (Baker 31). Famous among slave narratives are Frederick Douglass' Narrative of the Life of Frederick Douglass, an American Slave (1845); Moses Roper's A Narrative of the Adventures and Escape of Moses Roper from American Slavery (1837); and Olaudah Equiano's The Interesting Narrative of the Life of Olaudah Equiano, or Gustavus Vassa, the African (1789). Equiano was kidnapped from eastern Nigeria, taken to West Indies, and was finally brought to slavery in Virginia (Barksdale and Kinnamon 5). His autobiography details his remembrance of his native culture and his experiences of slavery. He implores the reader:

I hope the reader will not think I have trespassed on his patience in introducing myself to him, with some account of the manners and customs of my country. They had been implanted in me with great care, and made an impression on my mind, which time could not erase, and which all the adversity and variety of fortune I have since experienced, served only to rivet and record: for, whether the love of one's country be real or imaginary, or a lesson of reason, or an instinct of nature, I still look back with pleasure on the first scenes of my life, though that pleasure has been for the most part mingled with sorrow (Barksdale and Kinnamon 14-15). Equiano's assertions foreshadow some of the sensibilities that later appeared in African-American writing.

It suffices to argue that many African-American writers after the eighteenth century could echo Olaudah's sentiment, in relation to their writings, that "I still look back with pleasure on the first scenes of my life, though that pleasure has been for the most part mingled with sorrow." One can relate Equiano's narrative strategy to those found in works such as Lorraine Hansberry's A Raisin in the Sun, Alice Walker's The Color Purple, Toni Morrison's Song of Solomon, and Alex Haley's Roots, all of which echo Equiano's sentiment about what Africa means to the soul of the African-American writer. In the eighteenth century, 
Africa was near to the minds of many slaves, for many of them had just been brought from Africa, and their folk life later gave birth to stories and songs which contained motifs associated with African folktales, legends, myths, praisesongs, and proverbs. These motifs generally include motion imagery, the presence of supernatural beings, the home of the spirit, the trickster, the sacredness of motherhood, game-playing, and verbal competition.

Rich in abstruse references to Africa, the Spirituals contributed to a great extent to the development of African-American poetry. A critic notes that "Musically the Spiritual belongs to that vast matrix of song sprung from African roots and nurtured on American soil" (Long and Collier 108). The famous Spirituals such as "Sometimes I Feel Like a Motherless Child," "Swing Low, Sweet Chariot," and "Crucifixion" contain the basic elements that differentiate them from any other European poetical forms to which some critics, ignorant of African musical idiosyncrasies and verbal contrivances, have compared them, suggesting their indebtedness to sources outside their African roots. They have survived because of "their immediate and compelling universality of appeal, through their untarnishable beauty," and "by virtue of being fundamentally and everlastingly human" (Long and Collier 313).

Furthermore, we need mention W. E. B. Dubois's contribution to the study of spirituals. Writing The Souls of Black Folk in 1903, he proudly claimed the spirituals' impact on his intellect: "And so before each thought that I have written in this book I have set a phrase, a haunting echo of these weird old songs in which the soul of the black slave spoke to men. Ever since I was a child these songs have stirred me strangely" (Dubois 181). Moreover, the overwhelming impact of the Spirituals is evident in the fact that each chapter of Dubois' The Souls of Black Folk is preceded by "a bar of the Sorrow Songs." Perhaps the most significant of Dubois's observations is that the spirituals contain many rhetorical contrivances that only careful analysis can unravel. One such subtlety is doubletalk for intentional disguise. Through double-talk, slaves could disguise the real meaning of their verbal utterances. For example, in the Old Testament songs, Egypt may represent the South; Pharaoh may represent the slave owner; the Israelites may represent the slaves; and crossing the Red Sea may represent escape from slavery. Also the double-talk serves as a narrative strategy that often accompanies many oral compositions; they are the very art of oral composition in that they use the symbolic words that represent the audience's own experience, heightened by references to universal events of cosmic scope.

By the beginning of the 1920's, the African-American writer had inherited a wellestablished literary tradition to draw upon for creation of new works and synthesis of artistic expressions of the previous three hundred years. The result was the Harlem Renaissance. In the 1920's the African-American writer, celebrating folk ways on the one hand and creating high art on the other, looked towards Africa for inspiration. The migration in the 
1920's of many Black people from the South to New York City contributed to a cultural fruition known today in American history as the Harlem Renaissance. Writer after writer rediscovered the richness of African cultural traditions through African-American folk songs, narratives, themes, styles, motifs, and ethics. Alain Locke (1886-1954), a brilliant scholar and cultural critic of the period said, "If the Negro is interested in Africa, he should be interested in the whole of Africa; if he is to link himself up again with his past and his kin, he must link himself up with all of the African peoples" (Long 305). Many writers did what Locke suggested. For example, James Weldon Johnson, one of the outstanding poets of the period, wrote a poem of enthusiastic invocation to ancestral Africa titled "O Black and Unknown Bards":

O black and unknown bards of long ago,

How came your lips to touch the sacred fire?

How, in your darkness, did you come to know

The power and beauty of the minstrel's lyre?

Who first from midst his bonds lifted his eyes?

Who first from out the still watch, lone and long,

Feeling the ancient faith of prophets rise

Within his dark-kept soul, burst into song? (Barksdale 486)

He concludes his apostrophized poem with, "You sang far better than you knew; the songs/ That for your listeners' hungry hearts sufficed."

Other poets of the Harlem Renaissance expressed comparable feelings. Langston Hughes wrote in "The Negro Speak of Rivers": "I built my hut near the Congo and it lulled me to sleep./ I look upon the Nile and raised the pyramids above it." Claude McKay romanticized Africa with intense nostalgia in "The Tropics in New York":

My eyes grew dim, and I could no more gaze;

A wave of longing through my body swept,

And, hungry for the old, familiar ways,

I turned aside and bowed my head and wept. (Barksdale 493)

In his Banjo and Banana Bottom, novels set in France and Jamaica respectively, McKay advanced his vision of the world according to African ethical standards. The themes in his collection of poems titled Harlem Shadows (1922) are no less characteristic.

The contributors to the Harlem Renaissance did not only proclaim the New Negro, they persistently immersed themselves in their African heritage. In The New Negro, Allain Locke edited essays that articulated the ideology of the movement. The ideology expunged the black contributions to world culture and its readiness for leadership, not only in the 
arts on which the movement focused, but in other spheres of human endeavors as well. He proclaims, "We must realize that in some respects we need what Africa has to give us" (Long and Collier 305). The tone of the movement was confident and assured, voiced with determination to forge a new course for race relations through the propagation of African culture vis-a-vis the awakened consciousness out of Harlem. Other outstanding AfricanAmerican writers who regarded Africa as a point of reference from which black history in the United States could be accurately analyzed were Jean Toomer, Countee Culeen, Zora Neale Hurston, Arna Bontemps, and Sterling A. Brown.

From 1960 to the present, African-American writers have employed African cultural traditions in multifarious ways. The works of Robert Hayden, Richard Wright, Ralph Ellison, James Baldwin, Gwendolyn Brooks, Amiri Baraka, Lorraine Hansberry, Nikki Giovanni, and Margaret Walker have further advanced African tradition in varying degrees. In the 1950 's and 1960's, more than any time before, Africa represented for the African-American writer, what Greek and Rome represented for white Europeans and Americans.

The events in the world contributed to this new development. For instance, World War II brought Africans and African-Americans closer together, for African and AfricanAmerican soldiers, fighting fascist racism and dying for Europe, remembered in a rude awakening that they themselves were subjected to injustice in colonial Africa and the segregated United States. In addition, Black students and African-American expatriates in European capitals, especially France, found brotherhood and solidarity, expressed in the poems of Sedar Senghor of Senegal, Aime Cessaire of Martinique, and Leone Damas of French Guiana and coined by Jean-Paul Sartre as the negritude ideology. In idealistic universalism, racism was viewed as a sickness threatening the welfare of universal human family. Thus, “James Baldwin's novels and essays popularized the Black man's cause and linked his identity problems with those of Black, Brown, and Yellow people everywhere the white man had ruled as colonial overlord" (Barksdale and Kinnamon 658-9). The artistic creation in the black community of the sixties was mingled with popular culture, termed "Black is beautiful." The poetry and essays of LeRoi Jones--who, for identity with Africa, changed his name to Amiri Baraka in 1967--testify to this mingling. In addition, Lorraine Hansberry's optimism for integration came out of her belief that African Americans must take courage from their ancestors in Africa by associating with the continent and its people, seeking cooperation with Africans in their struggle for independence and economic justice.

The African-American literature in the seventies and eighties had much to borrow from African themes even when the subject was immediate experience in the community in the United States. One way to explain an experience has been to go back to Africa to look for answers. Some of these works include Paul Marshall's Brown Girl, Brownstones, Ishmael Reed's Mumbo Jumbo (1978), John A. Williams' The Man Who Cried I Am. 
Many of the feminist novels of the 1970's and 1980's set some of their plots in Africa. "The extent to which Afro-American women writers in the seventies and eighties have been able to make commitment to an exploration of self, as central rather than marginal, is a tribute to the insights they have culled in a century or so of literary activity. For AfroAmerican women writers today are no longer marginal to literature in this country. Many of them are its finest practioners" (Christian 176). The exploration of self takes the black feminist writer to Africa. Thus, many of the following novels are set in Africa or infer that the new moral strength takes its source from the ancient wisdom of Africa: Toni Morrison's Song of Solomon (1978) and Tar Baby (1980); Gloria Naylor's The Women of Brewster Street (1980); Toni Cade Bambara's The Salt Eaters (1980); Alice Walker's You Can 't Keep a Good Woman Down (1981) and The Color Purple (1982); Joyce Carol Thomas' Marked by Fire (1982); Ntozake Shange's Sassafras, Cypress and Indigo (1982); Audre Lorde's Zami (1982); and Paule Marshall's Praisesong for the Widow (1983). The identity crisis is not one of the predicaments that the character faces in one of these novels, whether she is facing the male dominated society or her own feelings toward the received order of a moral system imposed on her by social conventions. "In fact, in many of these novels, Africa and African women become important motifs for trying out different standards of new womanhood" (Christian 181). Africa is no longer viewed from a distance as it was for the slave writers and singers of the eighteenth century. On the contrary, some of the protagonists in the African-American novels of the 1970's and 1980's have lived in or traveled to Africa which, in the contemporary African-American consciousness, is no longer a lost home.

Conventional critical approaches to African-American literature require modifications if their aim is to discover the richness of the rhetorical strategies employed by the author. Also, by studying the varying degrees in which the African-American writer has taken African subjects or motifs as inspiration or the ethos of fictional or real world, one gains insight into the necessity of changing unsubstantiated assumptions. The study of African traditions in African-American literature expands our understanding and increases our appreciation of the artistry that the writer brings to bear on self-expression.

\section{Works Cited}

Baker, Houston A. Blues, Ideology, and Afro-American Literature: A Vernacular Theory.

Chicago: University of Chicago Press, 1984.

Barksdale, Richard and Keneth Kinnamon, eds. Black Writers of America: A Comprehensive Anthology. New York: Macmillan Publishing Co., Inc., 1972.

Christian, Barbara. Black Feminist Criticism: Perspectives on Black Women Writers. New York: Pergamon Press, 1985. 
Dubois, W. E. B.. The Souls of Black Folk. New York: Fawcett World Library, 1961.

Gates, Jr. Henry Louis, ed. Black Literature and Literary Theory. New York: Menthuen, Inc., 1984.

---. Figures in Black: Words, Signs, and the 'Racial Self. New York: Oxford University Press, 1987.

---. The Signifying Monkey: A Theory of African-American Literary Criticism. New York: University Press, 1988.

Herskovits, Melville J. The Myth of the Negro Past. Boston: Beacon Press, 1958.

Long, Richard A. and Eugenia W. Collier, eds. Afro-American Writing: An Anthology of Prose and Poetry, 2nd ed. University Park, Penn.: The Pennsylvania State University Press, 1985.

Shaw, J. T. "Literary Indebtedness and Comparative Literary Studies." Comparative Literature:

Method and Perspectives. Eds. Newton P. Stallknecht and Horst Frenz. Rev. ed.

Carbondale: Southern Illinois University Press, 1971. 